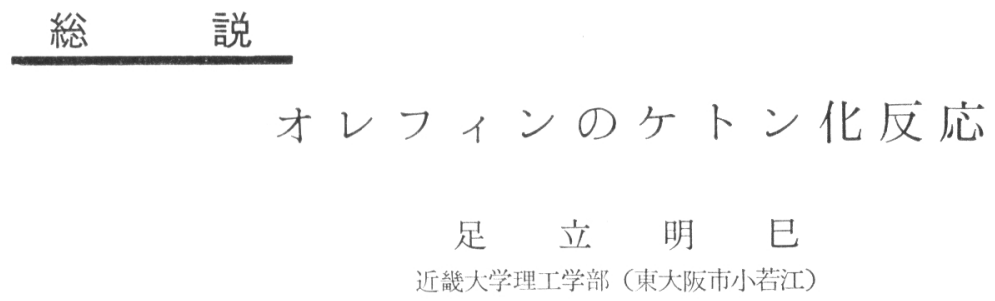

Ketonation Reaction on Olefins

\section{Akemi ADACHI}

Faculty of Science and Engineering, Kinki University

(Kowakae, Higashiōsaka-shi)

\section{1 緒言}

炭素一炭素二重結合を有する化合物を酸化すると，化 合物の構造, 酸化剤の種類, 反忘の条件などによって次 記のような種々の生成物を与える。しかし，一般にはお のおのの反応が並起したり, 二重結合の開裂を伴ったり する場合も多い。

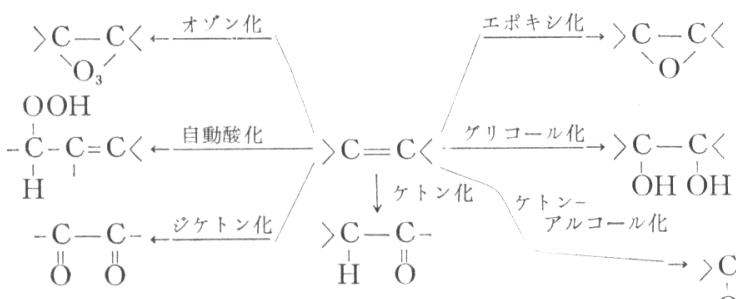

これら反応のらちでエポキシ化, グリコール化, 自動 酸化，オジン化についてはよく研究されている。

ケトン化は低級オレフィンについては工業化されてい る。(編集委員会より) 高級オレフィンや不飽和脂肪酸 のケトン化(に関して書くようにとのことであるが，こ れら化合物について）の研究例は少ない。そこで間接的 手段によるケトン化についても述べることにする。

\section{2 金属イオンによる酸化}

オレフィンのパラジウム (II), 水銀 (II), タリウム (III), 鉛 (IV) イオンなどの 金属イオン酸化では，カル ボニル化合物，グリコールなどを生ずる。これら反応の 反応速度, 反応機構などに関しては, すでに書かれた総 説 ${ }^{1)}$ を参照していただくことにして，ここではケトン化 の反応例のみについて述べる。

\section{$2 \cdot 1$ パラジゥム (II) イオンによる酸化}

パラジウム塩水溶液中に, オレフィンと酸素を吹き込 んでアルデヒドまたはケトンを製造する方法のうち，低 級オレフィンについては工業化され Wacker 法と呼ば

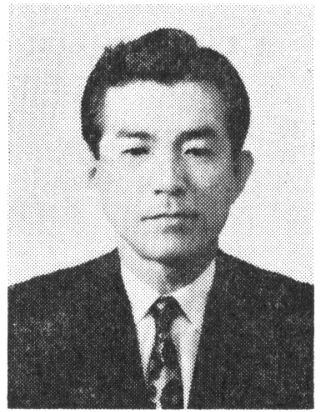

れている。

この方法は，つぎに示すよらに酸化剂として塩化パラ ジウムの水溶液を用い, そのパラジウムを二価のイオン 状態にとどめるために酸素および塩化第二銅を加えて反 忘させている。

$\mathrm{O}$

$\mathrm{PdCl}_{2}+\mathrm{RCH}=\mathrm{CH}_{2}+\mathrm{H}_{2} \mathrm{O} \rightarrow \mathrm{RC}-\mathrm{CH}_{3}+\mathrm{Pd}+2 \mathrm{HCl}$ $\mathrm{Pd}+2 \mathrm{CuCl}_{2} \rightarrow \mathrm{PdCl}_{2}+2 \mathrm{CuCl}$

$2 \mathrm{CuCl}+1 / 2 \mathrm{O}_{2}+2 \mathrm{HCl} \rightarrow 2 \mathrm{CuCl}_{2}+\mathrm{H}_{2} \mathrm{O}$

しかし，高級の かオレフィンにおいてはここ の反応が容易に起こらず，たとえ低収率で得られ たとしても，他のケトン異性体老多量に混人する ため，その单離が非常に困難である(表-1)。

W.H. Clement $ら^{3)}$ は溶剤としてジメチルホ $\mathrm{OH} \stackrel{\text { I }}{\mathrm{O}}$

ルムアミドの水溶液を用いることにより, 高級 ひーオレフィンから $80 \%$ 以上の高収率で純度の高いメチ ルケトンを得た。たとえば，1-ドデセンについて，0.20 $\mathrm{mol}$ の塩化パラジウム, $0.20 \mathrm{~mol} の \mathrm{CuCl}_{2} \cdot 2 \mathrm{H}_{2} \mathrm{O}, 0.20$ $\mathrm{mol}$ の 1-ドデセンを用い, $60 \sim 70^{\circ} \mathrm{C}$ で, $3.3 l / \mathrm{hr}$ の酸 素を通す条件で，ジメチルホルムアミド (DMF) と水 の割合がドデカンー2-オンの収率に及ぼす影響を調べた 結果が表-2 で, 最高収率は $87 \%$ である。

表-1 Pd(II) 塩によるオレフィンの酸化

\begin{tabular}{|c|c|c|c|c|}
\hline $\begin{array}{l}\text { 脂肪族モチ } \\
\text { オレフィン }\end{array}$ & $\begin{array}{c}\text { 反 应 } \\
\text { 温 度 } \\
\left({ }^{\circ} \mathrm{C}\right)\end{array}$ & $\begin{array}{l}\text { 㕛应 } \\
\text { 時 間 } \\
\text { (min) }\end{array}$ & カルボニル化合物 & $\begin{array}{l}\text { 収率 } \\
(\%)\end{array}$ \\
\hline エチレン & 20 & 5 & アセトアルデヒド & 85 \\
\hline プロピレン & 20 & 5 & アセトン & 90 \\
\hline 1 1ーブテン & 20 & 10 & メチルエチルケトン & 80 \\
\hline 1ヘペンテン & 20 & 20 & $n$ n-プロピルメチルケトン & 81 \\
\hline 1-ヘキセン & 30 & 30 & nーブチルメチルケトン & 75 \\
\hline 1-ヘプテン & 50 & 30 & $n$ nーアミルメチルケトン & 65 \\
\hline 1-オクテン & 50 & 30 & n-ヘキシルメチルケトン & 42 \\
\hline 1 1ーノネン & 70 & 45 & n-ヘプチルメチルケトン & 35 \\
\hline $1-$ デ セン & 70 & 60 & nーオタチルメチルケトン & 34 \\
\hline
\end{tabular}


U

表-2 $\mathrm{C}_{10} \mathrm{H}_{21} \mathrm{CH}=\mathrm{CH}_{2} \rightarrow \mathrm{C}_{10} \mathrm{H}_{21} \stackrel{\mathrm{C}}{\mathrm{C}} \mathrm{CH}_{3}$

\begin{tabular}{|c|c|c|c|c|}
\hline \multirow{2}{*}{ 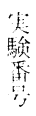 } & 溶 & 剂 & \multirow{2}{*}{ 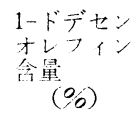 } & \multirow{2}{*}{$\begin{array}{l}\text { 収 } \\
(0)\end{array}$} \\
\hline & $\begin{array}{r}\text { DMF } \\
(\mathrm{ml})\end{array}$ & $\begin{array}{l}\mathrm{H}_{2} \mathrm{O} \\
(\mathrm{ml})\end{array}$ & & \\
\hline 1 & & 25 & 84 & () \\
\hline 2 & 50 & 4 & $96^{\circ}$ & 78 \\
\hline 3 & 50 & 7 & 96 & 78 \\
\hline 4 & 50 & 7 & 94 & 81 \\
\hline 5 & 50 & 7 & 84 & 85 \\
\hline 6 & 50 & 7 & 96 & 87 \\
\hline 7 & 50 & 10) & 84 & 85 \\
\hline 8 & 40 & 15 & 96 & 51 \\
\hline 9 & 25 & 25 & 84 & 20 \\
\hline
\end{tabular}

间椂にして，10-ウンデセン酸から１0 ケトウンデカン酸走収摔 $83 \%$ で得ている。 また，酸㮃抢よび銅塩のかわりに ジキノン在使用しても，1-ドデセンから收 率 $77 \%$ でドデカン--2ーオンが得られる。

W.G. Lloyd ら"はアルコール性ハラジ ウム（川）賉によるオレフィンの较化走行 尔う上相当するア七タールまたはケタール 它件成するが，少匯の水を存在させること によりカルボニル化合物を遊離の状態で,

表 3 に示すように ルケトンを高収率で得ている。

$$
\begin{aligned}
\mathrm{R}^{\prime} \mathrm{CH}= & \mathrm{CHR}^{\prime \prime}+2 \mathrm{ROH}+\mathrm{PdX}_{2} \\
& \rightarrow \mathrm{R}^{\prime} \mathrm{CH}_{2} \mathrm{CR}^{\prime \prime}(\mathrm{OR})_{2}+2 \mathrm{HX}+\mathrm{Pd}(\mathrm{O})
\end{aligned}
$$

\section{$2 \cdot 2$ 水銀（II）イオンによる酸化}

酸化第二水銀在トリフルオル酢酸水溶液に溶かしてト リフルオル酶酸水銀の酸性水溶液とし、これにプロピし ンを作用するとアクロレイン（収率 $36 \%$ ）とアセトン

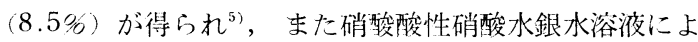
りプロビレンを酸化するとアセトンが，1-ブテンを酸化 するよメチルエチルケトンが得られだ) といら報告はあ るが，高級オレフィンに関する報告はい束だにないよう である。

$$
\begin{aligned}
\mathrm{CH}_{2}=\mathrm{CHCH}_{3} \frac{\mathrm{Hg}(\mathrm{OOCCF})_{2}-\mathrm{CF}_{3} \mathrm{COOH}-\mathrm{H}_{2} \mathrm{O}}{2 \mathrm{hr}, \text { 嘾流 }} \rightarrow \\
\mathrm{CH}_{2}=\mathrm{CHCHO}-\mathrm{CH}_{3} \mathrm{COCH}_{3}
\end{aligned}
$$$$
\mathrm{CH}_{3} \mathrm{CH}_{2} \mathrm{CH}=\mathrm{CH}_{2}
$$

$$
\stackrel{\mathrm{Hg}\left(\mathrm{NO}_{3}\right)_{2}-\mathrm{HNO}_{3}-\mathrm{H}_{2} \mathrm{O}}{\rightarrow} \rightarrow \mathrm{CH}_{3} \mathrm{CH}_{2} \mathrm{COCH}
$$

\section{$2 \cdot 3$ タリゥム (III) イオンによる酸化}

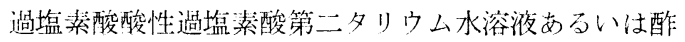
酸酸性酶酸第二タリウム水溶液によりオレフィン在酸化 する上飽和カルボニル执よびグリコールが生成する゙。 これら而生成物生成の選択性は表-4 に示すようにオレ

\begin{tabular}{|c|c|c|c|c|c|}
\hline オレフィン & フルコール & 触 & $\begin{array}{l}\text { 条 } \\
\text { 件: }\end{array}$ & it 成 & $\left.\begin{array}{c}\left.4 Q_{1}^{3} a\right) \\
(0) \\
0\end{array}\right)$ \\
\hline Xチレン & エタンジナール & $\mathrm{b}$ & $c$ & 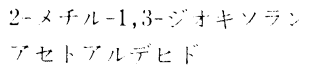 & $\begin{array}{r}91 \\
9\end{array}$ \\
\hline エチレン & $\begin{array}{l}\text { ブロバンー } \\
\text { 1,3ージオール }\end{array}$ & b & $\mathrm{c}$ & 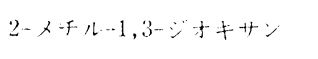 & High \\
\hline ーブテン & $\begin{array}{c}\text { エタンジオール } \\
\text { (鼬) }\end{array}$ & d & c & 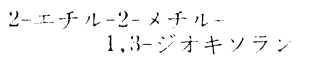 & 68 \\
\hline & & & & $2-y<)$ & 30 \\
\hline 一ハキセン & フロハノール-1 & $\mathrm{e}$ & $f$ & 2ー八キ少： & $\%$ \\
\hline & & & & 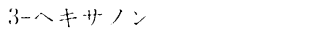 & 25 \\
\hline 一オクテン & プロハノール-1 & $\mathrm{e}$ & $\mathrm{g}$ & オク夕ノン & 89 h) \\
\hline & & & & 2-子夕父ノ: & 87 \\
\hline & & & & 3ーオりタ人 & $1 . j$ \\
\hline & & & & 1一力名1: & Tr. \\
\hline ーナクテン & フロハノールー1 & $\mathrm{e}$ & $\mathrm{i}$ & $+151=$ & 8()$\left.^{h}\right)$ \\
\hline & & & & 2-十タタ人: & 68 \\
\hline & & & & 3-オクタノン & 9 \\
\hline & & & & $1+ク 久 1:$ & 3 \\
\hline ーナクン & フロハノール-1 & e & $\mathrm{j}$ & $+42,2$ & $73^{h)}$ \\
\hline & & & & 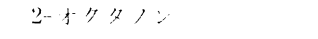 & 45 \\
\hline & & & & 3-オクタ人ン & 18 \\
\hline & & & & 1-15分 & 10 \\
\hline
\end{tabular}
フィンの種類によ一て異なり，生成する速度はイソブテ ンタプロピレン〜1-ブテン -cis-2-ブテンーtrans-2-ブ

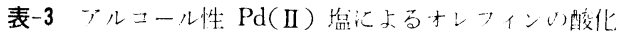

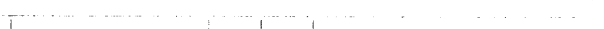

f) $50^{\circ} \mathrm{C}$, 酸始1: $3 \mathrm{~atm}, 120 \mathrm{~min}$

g) $30 \mathrm{C}$, 酸晫 $3 \mathrm{tatm}, 120 \mathrm{~min}$

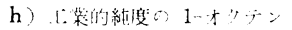

i ) $60 \mathrm{C}$, 輅 $3 \mathrm{~atm}, 120 \mathrm{~min}$

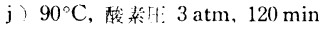

テン》エチレンの順になり，浴液のイオン强度が大きい ほど，反态速度定数は大きい，

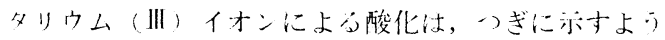
にタリウム塩とオレフィンり付加化合物を通。て進む上 考えられている

$$
\mathrm{Tl}^{3+}+\mathrm{CH}_{2}=\mathrm{CH}_{2} \rightleftharpoons\left[\begin{array}{ccc}
\mathrm{H}_{2} \mathrm{C} & & \\
& \ddots & \mathrm{Tl} \\
\mathrm{H}_{2} \mathrm{C} & \ldots
\end{array}\right]
$$

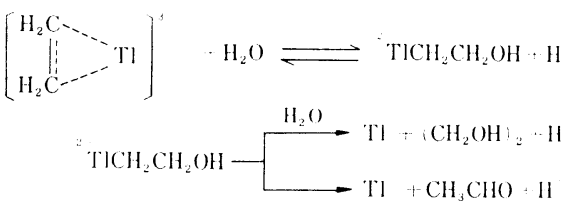

A. Mckillop ら ${ }^{8)}$ は硝挃夕りウムのメ夕ノ一ル溶液を オレフィンのメタノール溶液に室温で滴下すると，たち にア七タール (V) が生成する。これを希硫酸で分解し てケトンあるいはアルデヒド（い）を高純度で収摔よく 得ている(表-5)

付加化含物 (II) O) C-Tl 結合が炭素陽イオンを残 して切れたのち， $\mathrm{R}_{1} 、 \mathrm{R}_{2}$ のどちらかの置換基が転位し て（VI）が生成する。転位が起こらない埸合にはグリコ ールのエーテル（IV）が生成する。したがってこの伩 は，転位しやすいアリル基が置換したオレフィン拈よび 環状オレフィンに有効である。鎖状オレフィンである 
表-4 オレフィンのタリウム（III）酸化による飽和力ルボニル おトでグリコールの收率

\begin{tabular}{|c|c|c|c|c|c|}
\hline \multirow[b]{2}{*}{ オレフィン } & \multirow[b]{2}{*}{ カルボニル化命物 } & \multicolumn{2}{|c|}{ カルボニル収率 } & \multicolumn{2}{|c|}{ グリコール収率 } \\
\hline & & $\begin{array}{c}\text { 滑聕溸酸 } \\
\text { 尔溶液系 } \\
(\%)\end{array}$ & $\begin{array}{c}\text { 酿酸 } \\
\text { 溶液亲 } \\
(\%)\end{array}$ & $\begin{array}{c}\text { 過䎋素酸 } \\
\text { 水溶淮系 } \\
(\%)\end{array}$ & $\begin{array}{c}\text { 酶 酸 } \\
\text { 溶淮䇣 } \\
(\%)\end{array}$ \\
\hline$I \mp L Y$ & アセトテルデヒド & 45 & 45 & 55 & 55 \\
\hline プロ & アセトン & $75 \sim 85$ & 81 & $15 \sim 25$ & 17 \\
\hline 1ーブ テ ン & メチルエチルットン & $45 \sim 55$ & 75 & $15 \sim 25$ & 16 \\
\hline cis-2-ブ テ ン & メチルエチルふトン & $65 \sim 80$ & $85 \sim 90$ & $<0.5$ & $<0.5$ \\
\hline 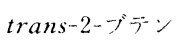 & メチルエチルケトン & $6.5 \sim 80$ & $85 \sim 90$ & $<0.5$ & $<0.5$ \\
\hline イソブテン & イソブチルデルデヒド & $35 \sim 45$ & 37 & $55 \sim 65$ & 52 \\
\hline
\end{tabular}

表-5 メタノール中ミ゙すオレフィンと硝酸タリウム（III）の/応

\begin{tabular}{|c|c|c|}
\hline オレフィン & 生成 & $\begin{array}{l}\text { 收 率: } \\
(\%)\end{array}$ \\
\hline pーメトキシスケレン & pーメトキシフィニルアセトナルデヒド & 75 \\
\hline 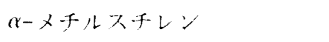 & フェニルナセトン & 81 \\
\hline 1,1-ジーp-アニシルエチレン & 4,4'-ジメトキシラ゙オキシベンゾイン & 95 \\
\hline 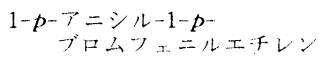 & 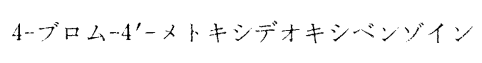 & 98 \\
\hline のーメチルスチルバン & 1,1-ジフェニルアセトン & 66 \\
\hline シクロヘキセン & シクロペンタンカルボキシアルデヒド & 85 \\
\hline シクロヘプテン & シクロヘキサンカルボキシアルデヒド & 86 \\
\hline 1-デセン & 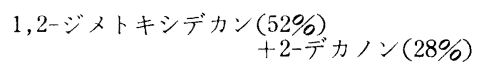 & 80 \\
\hline
\end{tabular}

プロパン類を生ずる場合

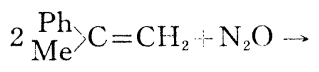

$\underset{\mathrm{Me}}{\mathrm{Ph}}>\mathrm{C}=\mathrm{O}+\underset{\mathrm{Me}}{\mathrm{Ph}}>\mathrm{C}\left\langle\underset{\mathrm{CH}_{2}}{\mathrm{CH}_{2}}+\mathrm{N}_{2}\right.$

一般に非置換エチレン，モ/置换 エチレンおよび多くの 1,2-ジ置換 エチレンは，这として（i）の型の 生成物を与え，1，1一ジ置換エチレン はほとんど（iii）型の生成物を生ず る。そして (ii) 型の反応は常に起 こる。たとえば，オートクレーブ中 でシクロヘキせン $40 \mathrm{ml}$ 老䡮酸作 空素と $300^{\circ} \mathrm{C}, 500 \mathrm{~atm}$ で $2 \mathrm{hr}$ 㑒 応するとシクロへキサノンが 23.5 $\mathrm{m} l$ 得られる。

この反忍の機構は, 再酸化空素の 共鳴構造 $(\stackrel{+}{\mathrm{N}}=\overline{\mathrm{N}}=\mathrm{O} \leftrightarrow \mathrm{N}=\stackrel{+}{\mathrm{N}}-\overline{\mathrm{O}})$ の陽性窒素の二重結合に対寸る攻撃 により生ずる五員環中閏体を通る機 構が考えられている。

$$
\stackrel{\mathrm{R}}{\mathrm{H}}>\mathrm{C}=\mathrm{C}\left\langle\mathrm{R}_{\mathrm{H}}^{\mathrm{R}^{\prime}}+\stackrel{+}{\mathrm{N}}=\overline{\mathrm{N}} \cdots \mathrm{O}\right.
$$

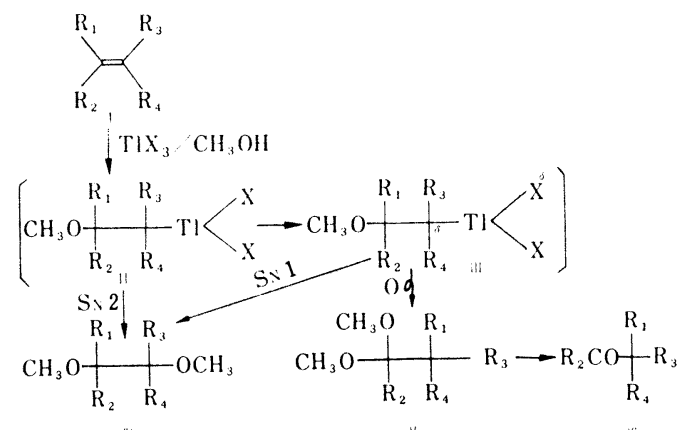

1-デセンの場合には，1,2-ジメトキシデカンの収率が $52 \%$ で 2-デカノンの収率は $28 \%$ である。

\section{3 試薬による酸化}

\section{$3 \cdot 1$ 亜酸化窒素 (一二酸化窒素) による酸化 ${ }^{9}$}

オレフィンは容易に亜酸化空素上反応し，つぎの種類 の反応生成物を生ずる。

i ）炭素数の等しいカルボニル化合物のみを生ずる場 合

$$
\langle\rangle+\mathrm{N}_{2} \mathrm{O} \rightarrow\langle\rangle=\mathrm{O}+\mathrm{N}_{2}
$$

ii）炭素数の減じたカルボニル化合物を生ずる場合

$$
\mathrm{CH}_{3} \mathrm{CH}=\mathrm{CHCH}_{2} \mathrm{CH}_{3}+2 \mathrm{~N}_{2} \mathrm{O}
$$$$
\rightarrow \mathrm{CH}_{3} \mathrm{CHO}+\mathrm{CH}_{3} \mathrm{CH}_{2} \mathrm{CHO}+2 \mathrm{~N}_{2}
$$

iii）オレフィンの 2 分子からカルボニルおよびシクロ

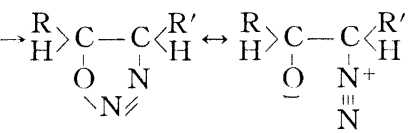

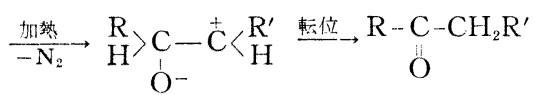

$$
\begin{aligned}
& +\mathrm{H}-\mathrm{C}-\mathrm{CHRR}^{\prime} \\
& \stackrel{\mathrm{O}}{ }
\end{aligned}
$$

\section{$3 \cdot 2$ クロム酸による酸化}

クロム酸によるオレフィンの酸化生成物としては，炭 素鎖の開裂を伴わないエポキシド, ケトール, カルボニ ル, カルボン酸, また開裂を伴らカルボニル, カルボン 酸があり, 環状オレフィンではしばしばアリル位の酸化 も起こるので, 複雑な樣相を呈する ${ }^{10)}$ 。

たとえば，2-メチルブテン-2(12.5g) を $55 \%$ の硫酸 に溶かした $\mathrm{CrO}_{3}$ で酸化すると 3-メチルブタン-2-オン (1.4 g) が得られる ${ }^{11)}$ 。

$$
\mathrm{Me}_{2} \mathrm{C}=\mathrm{CHMe} \frac{\mathrm{CrO}_{8}\left(55 \% \mathrm{H}_{2} \mathrm{SO}_{4}\right)}{0^{\circ} \mathrm{C}} \rightarrow \mathrm{Me}_{2} \mathrm{CHCOMe}
$$

オレフィンのクロム酸酸化は, 過マンガン酸酸化のと きのような環状エステルを経由するかどうかについて は，はっきりした結論は出ていないようである ${ }^{12)}$

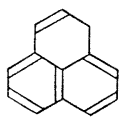
$\frac{\mathrm{Na}_{2} \mathrm{Cr}_{2} \mathrm{O}_{7}\left(\mathrm{CH}_{3} \mathrm{COOH}\right)}{\text { 收率 } 83 \%}$

ベリナフテン

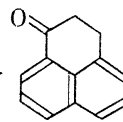
7ーペリナフタノン 
表-6オレフィンの塩化クロミル酸化

\begin{tabular}{|c|c|c|c|c|c|}
\hline オ $レ フ ィ ン$ & 方 法 & 開 環 生 成 物 & 収 $(\%)^{\text {涬 }}$ & 主生成物 & 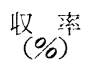 \\
\hline 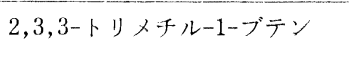 & $\begin{array}{l}\mathrm{A} \\
\mathrm{B}\end{array}$ & ピナコロン & $\begin{array}{l}10.8 \\
<1.0\end{array}$ & 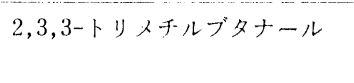 & $\begin{array}{l}28.7 \\
34.9\end{array}$ \\
\hline $2,4,4$-トリメチルー1ーペンテン & $\begin{array}{l}\text { A } \\
\text { C }\end{array}$ & 3,3-ジメチルー2-ペンタノン & $\begin{array}{l}4.8 \\
0\end{array}$ & 2,4,4ートリメチルペンタナール & $\begin{array}{l}38.3 \\
75.8\end{array}$ \\
\hline $\begin{array}{l}\text { 4,4-ジメチル-2- } \\
\text { ネオペンチルー1-ペンテン }\end{array}$ & $\begin{array}{l}\mathrm{A} \\
\mathrm{C}\end{array}$ & ジネオペンチルケトン & $<1$ Tr. & $\begin{array}{l}\text { 4,4-ジメチルー2- } \\
\text { ネオベンチハンタナール }\end{array}$ & $\begin{array}{l}54.8 \\
80.8\end{array}$ \\
\hline 2,3-ジィチル-2-ブテン & $\mathrm{A}$ & アセトン & 6.2 & ピナュロン & 50 \\
\hline
\end{tabular}

今法 $\mathrm{A}$ : 二酸化イオウ, B : 曹鉛末

重ク口ム酸酸化によるケトン化には，つぎのような特 殊な例が二，三あるのみである

塩化クロミルでオレフィンを酸化 (Étard 反忘) する と, 通常いるいるな生成物の混合物が低収率で得られ る14)。たヒえば

$$
\begin{aligned}
& \text { 1一八未たン } \mathrm{CrO}_{2} \mathrm{Cl}_{2} \text { 酸化 } \rightarrow
\end{aligned}
$$

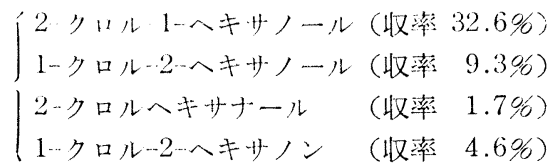

F. Freeman $5^{15}$ は, 従来の方法ではオレフィン一塩 化ク口ミル付扣物を二酸化イオウで還元的加水分解を行 ないカルボニル化合物を含成したが，アルデヒドの重合 触媒である二酸化イオウよりも, さらに還元作用があり 重台触媒でない雨鉛末を用いて付加物を還元することに よりカルボニル化合物をよい収率（表-6）で得た。

反応機構はつぎのように考えられている。

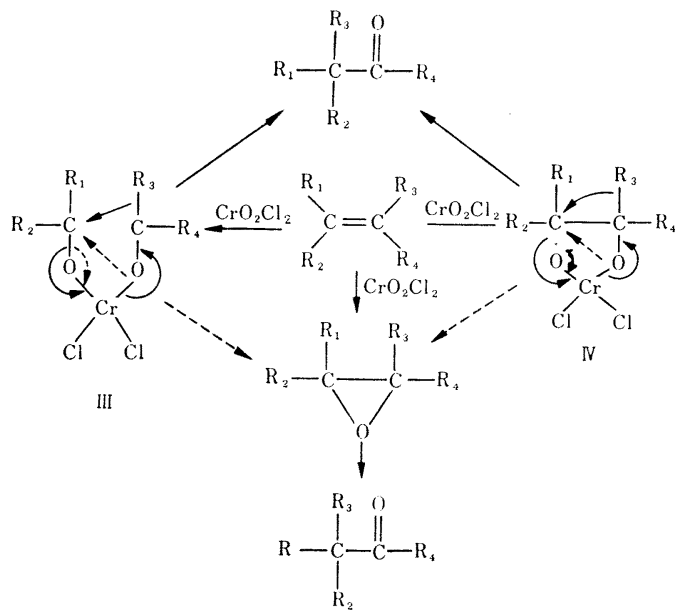

\section{$3 \cdot 3$ 有機過酸による酸化}

過酸はオレフィンと反态して容易にエポキシ化合物を 生ずる。エポキシ化は酸性で行なわれることが多いか ら，しばしば同時に転位生成物を生ずることがある。と くに強酸から調製した過酸や, 求電子試薬を触媒として
用いると顕著である。

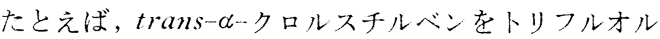
過酶酸，渦酢酸，過安息香酸でエポキシ化すると， $\alpha$ 一ク

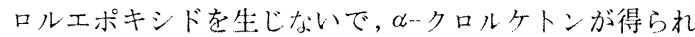
る $^{(1)}$ 。

$$
\begin{aligned}
& \underset{\mathrm{H}}{\mathrm{C}_{6} \mathrm{H}_{5}}>\mathrm{C}=\underset{\mathrm{C}}{\mathrm{C}} \mathrm{C}_{6} \mathrm{H}_{5}+\mathrm{CF}_{3} \mathrm{CO}_{3} \mathrm{H} \\
& \mathrm{O} \mathrm{Cl}
\end{aligned}
$$

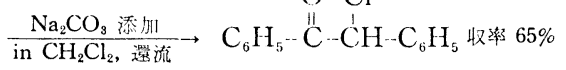

また,オレフィンの塩化メチレン溶液中に $0 \sim 8^{\circ} \mathrm{C}$ で, あらかじめ調製したトリフルオル過酢酸の塩化メチレン 溶液および三フッ化ホウ素のエーテラートを同時に滴下 し, $0^{\circ} \mathrm{C}$ で $15 \mathrm{~min}$ かきまぜるとカルボニル化会物が直接 得られる(表-7)。この反応の機構は，まず二重結合に ヒドロキシ陽イオンが攻撃し，その後 Wagner-Meerwein 転位が起こりカルボニル化合物が得られるものと 考えている ${ }^{17)}$ 。

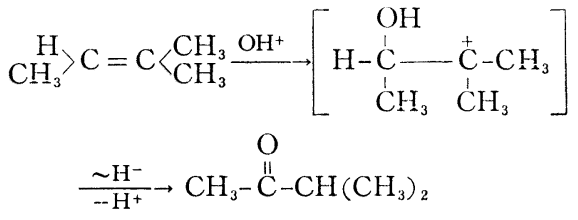

そのほかに過ギ酸，過酢酸，過安息香酸，モノ過フ夕 ル酸による，つぎに示すような特殊なオレフィンに関す る報告もいくつかある ${ }^{18)}$ 。

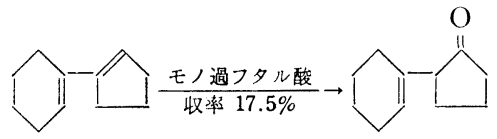

\section{4 イオウを含む試薬による酸化 ${ }^{19)}$}

直鎖または環状オレフィンをイオウ，アンモニア，硫 化水素および多量の水を含む閉鎖系で加圧下，約 200〜 $350^{\circ} \mathrm{C}$ で反応させると 40 50 $\mathrm{mol}$ の収率でケトンが得 られる。副生成物はおもに異性化したオレフィン，メル カプタン，スルフィドである。

たとえば，1-オクテンを反応温度 $300^{\circ} \mathrm{C}$, 反忘時間 15 $\min$ で酸化試薬の使用割合とケトンの収率との関係を 調べた結果が 表-8 である。 
表-7 トリフルオル過酶酸と三フッ化ホウ素による酸化

\begin{tabular}{|c|c|c|}
\hline オレフィン & 生 成 & $\begin{array}{l}4 \times \text { 率 } \\
(\%)\end{array}$ \\
\hline 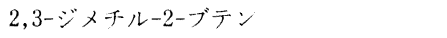 & 3,3-ジメチルー2-プタノン(ピナョロン) & 75 \\
\hline 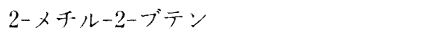 & 3ーメチル-2-ブタノン & 53 \\
\hline cis-3-メチル-2-ペンテン & 3ーメチルー2-ヘンタノン & 63 \\
\hline trans-3-メチル-2-ペンテン & 3-メチル-2-ペンタノン & 70 \\
\hline 1ーメチルシクロヘキセン & 2-メチルシクロヘキサノン & 41 \\
\hline 1,2-ジメチルシクロへキセン & 1ーアセチルー1ーメチルシクロペンタン & 76 \\
\hline$J^{9,10}$ オクタリン & スヒロ $[4,5]$ デカンー6-オン & 86 \\
\hline 3-クロル-2-メチル-2-プテン & 3-クロル-3-メチル-2-ブタノン & 77 \\
\hline 3-ブロム-2-メチル-2-ブテン & 3-ブロムー3-メチルー2-ブタノン & 79 \\
\hline 2,3-ジプロムー2ーブテン & 3,3-ジブロム-2-ブタノン & 61 \\
\hline 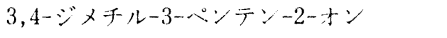 & 3,3-ジメチル-2,4-ペンダオン & 81 \\
\hline 2-シクロペンチリデンシクロペンタノン & スピロ $[4,5]$ デカン -6,10-ジオン & 43 \\
\hline
\end{tabular}

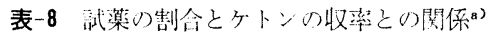

\begin{tabular}{|c|c|c|c|c|c|c|c|c|c|}
\hline $\begin{array}{l}\text { 実験 } \\
\text { 番号 }\end{array}$ & $\left|\begin{array}{c}1-\text { オク } \\
\text { テン } \\
(\mathrm{mol})\end{array}\right|$ & $\left|\begin{array}{c}\text { イオウ } \\
\text { (g-原子) }\end{array}\right|$ & $\begin{array}{l}\mathrm{NH}_{8} \\
(\mathrm{~mol})\end{array}$ & $\begin{array}{l}\mathrm{H}_{2} \mathrm{~S} \\
(\mathrm{~mol})\end{array}$ & $\begin{array}{l}\mathrm{H}_{2} \mathrm{O} \\
(\mathrm{mol})\end{array}$ & $\begin{array}{c}\text { 転化婆 } \\
(\%)\end{array}$ & $\begin{array}{l}\text { オク多 } \\
(\text { wt } \%)\end{array}$ & $\begin{array}{l}\text { オ”タン } \\
\text { 酸 } \\
(w t \%)\end{array}$ & $\begin{array}{l}\text { 低沸点物 } \\
\text { 筫 } \\
(w+\%)\end{array}$ \\
\hline 1 & 0.40 & 0.25 & 0.23 & 0.18 & 6.2 & 83 & 61 & 0 & 0.5 \\
\hline $2^{b)}$ & 0.40 & 0.60 & 0.23 & 0.17 & 6.2 & 93 & 29 & 3.4 & 2 \\
\hline $3^{c)}$ & 0.40 & 0.85 & 1.71 & 0.16 & 4.1 & $>95$ & - & 20 & - \\
\hline 4 & 0.60 & 0.40 & 0.33 & 0.25 & 6.9 & 92 & 51 & 0 & 0.2 \\
\hline 5 & 0.60 & 0.38 & 0.67 & 0.25 & 7.2 & 86 & 44 & 0 & 0.2 \\
\hline $6^{\mathrm{d})}$ & 0.60 & 0.50 & 0.51 & 0.44 & 6.8 & 91 & 21 & Tr. & - \\
\hline 7 & 0.60 & 0.40 & 0.33 & 0.09 & 6.9 & 92 & 49 & 0 & 0.3 \\
\hline 8 & 0.60 & 0.40 & 0.15 & 0.15 & 12.6 & 90 & 52 & 0 & 0.3 \\
\hline 9 & 0.60 & 0.40 & 0 & 0.29 & 6.7 & 81 & 27 & 0 & 0.8 \\
\hline
\end{tabular}

a) 実䮖番号 $3\left(230^{\circ} \mathrm{C}, 30 \mathrm{~min}\right)$, 生成物さ主としてメルカプタンとスルフィドー゙るる

b) 暗色生成物

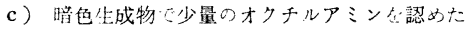

d) 暗色生成物に5\%のオクチルアミンた分離した

生成したオクタハンはオクタン-2-オン (76 wt \%), オクタンー3-オン $(20 \mathrm{wt} \%)$ 打よびオクタン 4 -オン

(4 wt\%) からなっている。

その他のオレフィンについても同様の反応を行ない，

ケトンを主生成物として得ている（表-9)。

ケトンが生成する機構はつぎのように考えられてい る。
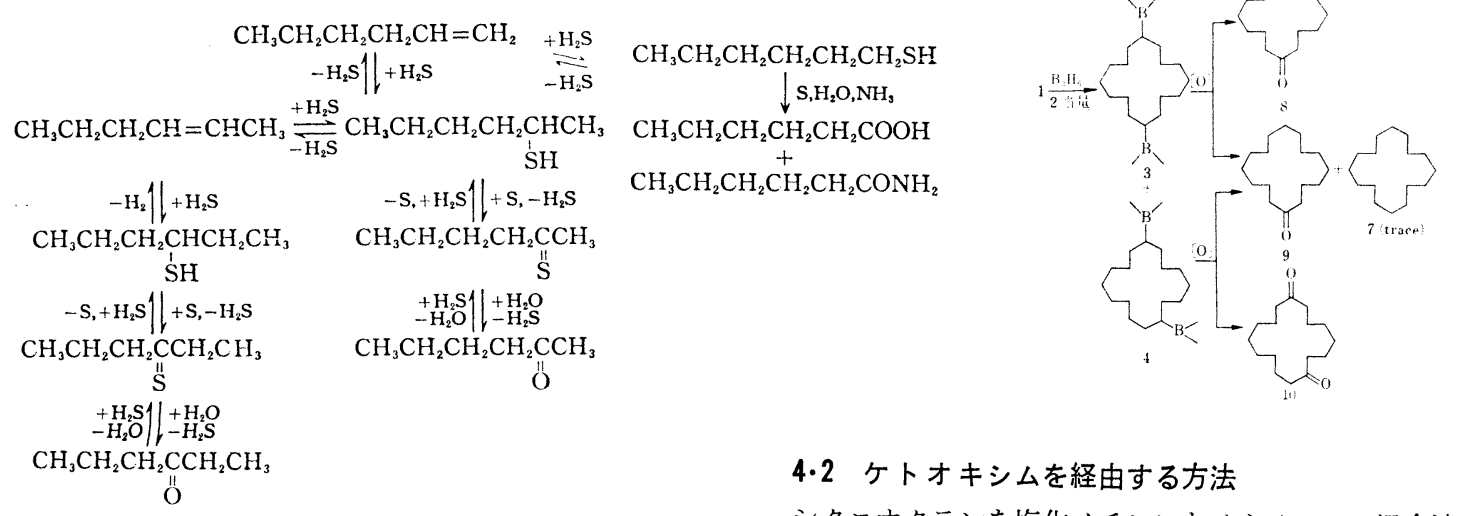

\section{4 間接的ケトン化}

\section{$4 \cdot 1$ 有機ホウ素化合物も経由} する方法

H.C. Brown ら ${ }^{20)}$ は環状オレフ インのエーテル溶液にジボランを 反応させたのち，クロム酸酸化を 行ない相当するケトンを収率よく 得た。

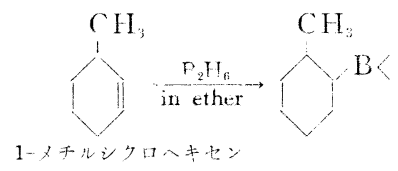

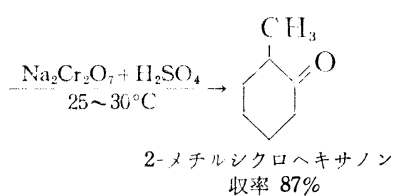

また，L.G. Wideman" ${ }^{21}$ は 1,9シクロヘキサデカジェン (1)をジ ボランで処理すると，ジボランの 使用量により中閪体 (2), (3), (4) が得られ, エーテル, 無水ク口ム 酸の硫酸酸性水溶液で酸化すると ケトン (5), (9),(8) および (10) 毒表-10 に示寸収率で得た。

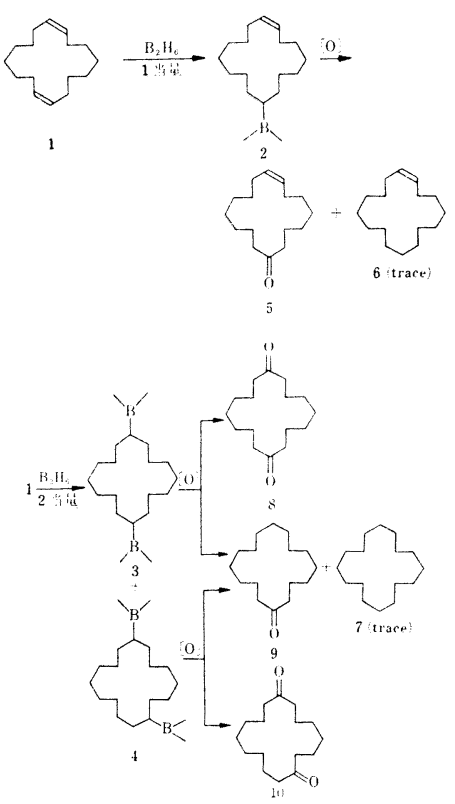

4.2 ケトオキシムを経由する方法

シクロオクテンを塩化メチレンとメタノールの混合溶 
表-9イオウを含む試薬によるオレフィンの酸化影

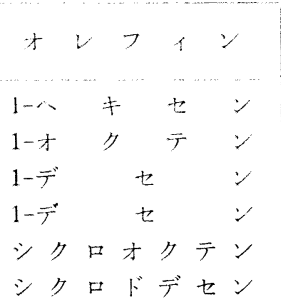

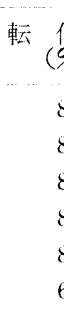

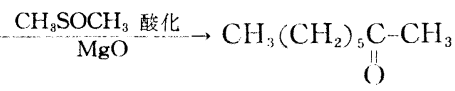

しかし、ヨードシクロヘキサンはシクロヘキサノンを 生成しないが，クロルシクロヘキサンは酢酸銀の存在 下，ジメチルスルホキシドと㖄熱することによりシクロ ヘキサノンが $9.7 \%$ の収率で得られる。

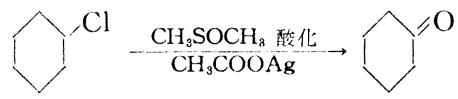

この酸化皮匛の機構はつぎのように考えられている。

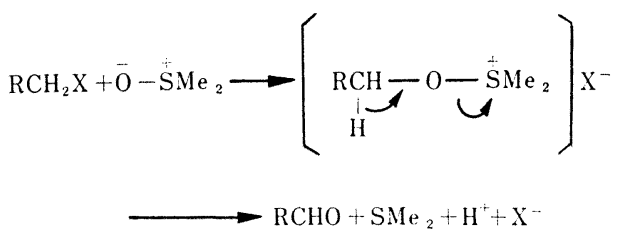

\section{$4 \cdot 4$ ハロゲンヒドロキシ誘導体を経由する方法}

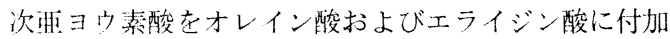
させをと，ヨウ素一ヒドロキシスステリン酸のジアステ レオアーが生成する。これを酶酸銀, 酢酸十トリウムの

表11 9(10),10(9)-ヨウ素ヒドロ丰システアリン酸メチル（I）

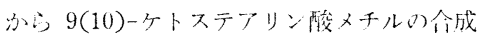

にかえ，酢酸クロムと $65^{\circ} \mathrm{C}$ に $16 \mathrm{hr}$ 反応させると シクロオクタノンが収率 $88 \%$ で得られる ${ }^{23)}$ 。

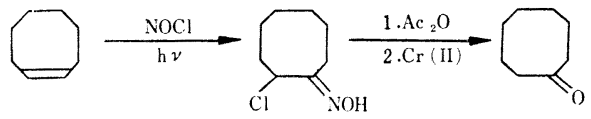

\begin{tabular}{|c|c|c|c|c|c|c|c|}
\hline \multirow{3}{*}{ No. } & \multirow{3}{*}{$\begin{array}{c}\mathrm{HgSO}_{4} / \mathrm{I} \\
\text { ENH }\end{array}$} & \multirow{2}{*}{$\begin{array}{l}\mathrm{H}_{2} \mathrm{SO}_{4} \\
\text { 浀 度 }\end{array}$} & \multirow{3}{*}{$\begin{array}{c}\text { 時 間 } \\
(h r)\end{array}$} & \multirow{2}{*}{ 㵊 府 } & \multicolumn{3}{|c|}{ 生成物U藾会 $(\%)$} \\
\hline & & & & & $\begin{array}{l}9(10)-3 \\
ト \times \div\end{array}$ & $\begin{array}{l}9,10-シ \\
ヒ ト ゙ ロ \neq\end{array}$ & $=($ 他 \\
\hline & & $(N)$ & & $\left({ }^{\circ} \mathrm{C}\right)$ & $\begin{array}{l}\text { リン酸メ } \\
\text { チル }\end{array}$ & $\begin{array}{l}\text { 少酸 } \\
\text { チル }\end{array}$ & 生成物 \\
\hline 1 & $\cdots \cdot$ & 0.5 & 3 & 70 & 12 & $\cdots$ & 88 \\
\hline 2 & - & 5.0 & 3 & 70 & 8 & $\cdots$ & 92 \\
\hline 3 & $2: 1$ & $\cdots$ & 3 & 70 & 67 & 21 & 12 \\
\hline 4 & $2: 1$ & $\ldots$ & 10 & 22 & 62 & 19 & 19 \\
\hline 5 & $2: 1$ & 0.05 & 3 & 70 & 75 & 12 & 13 \\
\hline 6 & $1: 1$ & 0.5 & 3 & 70 & 80 & - & 20 \\
\hline 7 & $2: 1$ & 0.5 & 3 & 70 & 94 & $\ldots$ & 6 \\
\hline 8 & $3: 1$ & 0.5 & 3 & 70 & 93 & - & 7 \\
\hline 9 & $2: 1$ & 5.0 & 3 & 70 & 85 & - & 15 \\
\hline 10 & $2: 1$ & 0.5 & 6 & 22 & 60 & - & 40 \\
\hline 11 & $2: 1$ & 0.5 & 10 & 22 & 93 & - & 7 \\
\hline 12 & $2: 1$ & 0.5 & 12 & 22 & 95 & - & 5 \\
\hline
\end{tabular}

\section{$4 \cdot 3$ ハロゲン化物を経由する方法 ${ }^{24)}$}

ヨウ化水素はオレフィンに Markownikow 則に従 う付加物が得られる。このヨウ化アルキルをジメチル スルホキシド中で加熱すると，相当するカルボニル化 合物が得られる。たとえば，2-ヨードオクタンを酸化 マグネシウムの存在下, ジメチルスルホキシドと 150 ${ }^{\circ} \mathrm{C}$ で $1 \mathrm{hr}$-加熱して酸化するとオクタンー2-オンが収 率 $32 \%$ で得られる。

$\mathrm{CH}_{3}\left(\mathrm{CH}_{2}\right)_{5} \mathrm{CH}=\mathrm{CH}_{2} \stackrel{+\mathrm{HI}}{\rightarrow} \mathrm{CH}_{3}\left(\mathrm{CH}_{2}\right)_{5} \mathrm{CH}-\mathrm{CH}_{3}$

I $\mathrm{H} \quad \mathrm{H} \mathrm{H}$

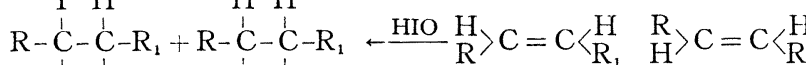

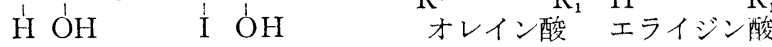

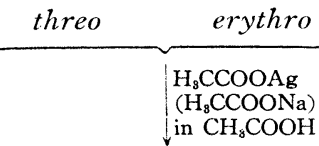

$\mathrm{H}_{3} \mathrm{CCOOH}$ $\mathrm{H} \mathrm{H}$ (cis)

(trans)
$\mathrm{I} \mathrm{H} \mathrm{H}$ $\underbrace{\begin{array}{c}\mathrm{R}-\stackrel{\mathrm{C}}{\mathrm{C}}-\stackrel{\mathrm{C}}{\mathrm{C}}-\mathrm{R}_{1}+\mathrm{R}-\stackrel{\mathrm{C}}{\mathrm{C}}-\stackrel{\mathrm{C}}{\mathrm{C}}-\mathrm{R}_{1} \\ \text { threo }\end{array}}_{\begin{array}{c}\mathrm{H} \mathrm{H}_{3} \mathrm{CCOOAg} \\ \left(\mathrm{H}_{3} \mathrm{CCOONa}\right) \\ \text { in } \mathrm{CH}_{3} \mathrm{COOH}\end{array} \mid}$
$\mathrm{H} \mathrm{H}$ $\mathrm{R}-\mathrm{CH}_{2}-\mathrm{C}-\mathrm{R}_{1}+\mathrm{R}-\stackrel{\text { C }}{\mathrm{C}}-\stackrel{\text { C }}{\mathrm{C}}-\mathrm{R}_{1}+\mathrm{R}-\stackrel{\mathrm{C}}{\mathrm{C}}-\stackrel{\mathrm{I}}{\mathrm{C}}-\mathrm{R}_{1}$
$\mathrm{R}-\stackrel{+}{\mathrm{C}}-\stackrel{\mathrm{C}}{\mathrm{C}}-\mathrm{R}_{1}+\mathrm{R}-\stackrel{\mathrm{C}}{\mathrm{C}}-\stackrel{\mathrm{C}}{\mathrm{C}}-\mathrm{R}_{1}+\mathrm{R}-\mathrm{CH}_{2} \mathrm{C}-\mathrm{R}_{1}$ H $\mathrm{H} \mathrm{H} \mathrm{H}_{3} \mathrm{CCOO}$ Oे $\mathrm{H}$

II $\mathrm{R}=\mathrm{H}_{3} \mathrm{C}\left(\mathrm{CH}_{2}\right)_{7}$ 一 あるいは - $\left(\mathrm{CH}_{2}\right)_{7} \mathrm{CO}_{2} \mathrm{H}$ $\mathrm{R}_{1}=-\left(\mathrm{CH}_{2}\right)_{7} \mathrm{CO}_{2} \mathrm{H}$ あるいは $\mathrm{H}_{3} \mathrm{C}\left(\mathrm{CH}_{2}\right)_{7}-$

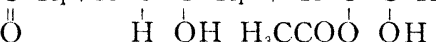


酢酸溶液中においてヒドロキシアセトキシステアリン酸 に変換する場合，約 $25 \%$ の 9(10)-ケトステアリン酸が 生成する ${ }^{25)}$ (前ページの式)。

そこで, D. Rankoff ${ }^{26)}$ は硫酸水銀, 硫酸の存在下, メタノール中でヨウ素ーヒドロキシステアリン酸メチル エステルを反応させて, 相当するケトエステルを直接合 成する方法を検討した結果が表-11 である。

90\% 以上の収率でケトエステルを得るには，ヨウ化 物では反応は $3 \mathrm{hr}$ でよいが，塩化物では $7 \mathrm{hr}$ ，臭化物 では $5 \mathrm{hr}$ が必要である。硫酸および硫酸水銀のかわり に硝酸および硝酸水銀を用いたときはケトエステルの収 率は低くなり，ジヒドロキシ酸エステルが生成する。

\section{5 エポキシドを経由する方法}

エポキシドを異性化するとカルボニル化合物 ${ }^{27}$ あるい は不飽和アルコール ${ }^{28)}$ が生成する。

ジコバルトオクタカルボニルはメタノールなどの極性 溶媒中では不均化して $\mathrm{C}_{0}(\mathrm{CO})_{4}{ }^{-}$が生成し, エポキシ ドを開環，ヒドリドイオンが移動してケトンに転換す る $^{29)}$ 。

$$
\begin{aligned}
& 3\left[\mathrm{Co}(\mathrm{CO})_{4}\right]_{2}+12 \mathrm{CH}_{3} \mathrm{OH} \\
& \rightarrow 2\left[\mathrm{Co}\left(\mathrm{CH}_{2} \mathrm{OH}\right)_{6}\right]^{2+}+\left[\mathrm{Co}\left(\mathrm{CO}_{4}\right)\right]_{2}{ }^{-}+8 \mathrm{CO}
\end{aligned}
$$

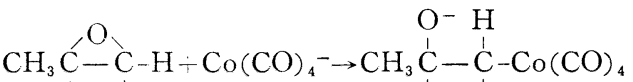$$
\mathrm{H} \mathrm{H}
$$$$
\mathrm{H} \quad \mathrm{H}
$$

$$
\begin{aligned}
\stackrel{\mathrm{O}}{\text { II }}-\mathrm{CH}_{3}+\mathrm{Co}(\mathrm{CO})_{4}- \\
\text { 收率 } 70 \%
\end{aligned}
$$

異性化触媒としてはルイス酸触媒がよく用いられる。 9,10-エポキシ ステアリン酸メチルは 1,4-ジオキサン 中， $100^{\circ} \mathrm{C}$ で塩化アルミニウムあるいは三フッ化ホウ素 エーテラート触媒を用いると，主として 9(10)ーケトス テアリン酸メチルに異性化する ${ }^{30)}$ 。

$$
\mathrm{O}
$$

$\mathrm{CH}_{3}\left(\mathrm{CH}_{2}\right)_{7} \mathrm{CH}-\mathrm{CH}\left(\mathrm{CH}_{2}\right)_{7} \mathrm{CO}_{2} \mathrm{CH}_{3}$

$$
\rightarrow \mathrm{CH}_{3}\left(\mathrm{CH}_{2}\right)_{7(8)}-\underset{\mathrm{O}}{\mathrm{C}}\left(\mathrm{CH}_{2}\right)_{8(7)}-\mathrm{CO}_{2} \mathrm{CH}_{3}
$$

収率 $\mathrm{AlCl}_{3}: 77 \%$

$$
\mathrm{BF}_{3} \text {-etherate : } 90 \%
$$

また，12,13-エポキシオレイン酸メチルをジオキサン 中で三フッ化ホウ素エーテラートと反応させると 12-お よび 13-ケトオレイン酸メチルが主生成物として得ら れ，そのほかにシクロプロパン化合物が同時に生成す る $^{31)}$ 。

$$
\begin{gathered}
\mathrm{CH}_{3}\left(\mathrm{CH}_{2}\right)_{4} \mathrm{CH}-\mathrm{CHCH}_{2} \mathrm{CH}=\mathrm{CH}\left(\mathrm{CH}_{2}\right)_{7} \mathrm{CO}_{2} \mathrm{CH}_{3} \\
\frac{\mathrm{BF}_{3} \text {-etherate }}{\text { in dioxane }} \rightarrow \\
\left\{\begin{array}{c}
\mathrm{CH}_{3}\left(\mathrm{CH}_{2}\right)_{4(5)}-\mathrm{CH}_{2}\left(\mathrm{CH}_{2(1)} \mathrm{CH}\right. \\
\mathrm{O} \quad \mathrm{CH}\left(\mathrm{CH}_{2}\right)_{7} \mathrm{CO}_{2} \mathrm{CH}_{3} \\
\mathrm{CH}_{3}\left(\mathrm{CH}_{2}\right)_{4}-\mathrm{CH}_{2} \mathrm{CH}-\mathrm{CH}\left(\mathrm{CH}_{2}\right)_{7} \mathrm{CO}_{2} \mathrm{CH}_{3} \\
\mathrm{O} \quad \stackrel{\mathrm{C} \mathrm{CH}_{2}^{\prime}}{\mathrm{O}}
\end{array}\right.
\end{gathered}
$$

G. Kolaczinski ら ${ }^{32)}$ は 1,2-エポキシ化合物をルイス 酸によって相当するアルデヒドに変化させる反応の条件 について検討し，反応機構はつぎのようであると考え た。

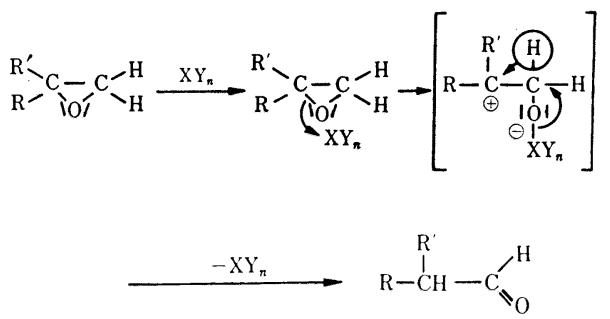

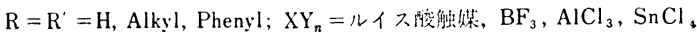

9,10-エポキシステアリン酸をジメチルスルホキシド と加熱すると 9(10)-ケトステアリン酸が 15〜20\%の 収率で得られたという報告がある ${ }^{33)} 。$

$$
\begin{gathered}
\mathrm{CH}_{3}\left(\mathrm{CH}_{2}\right)_{7} \mathrm{CH}-\mathrm{CH}\left(\mathrm{CH}_{2}\right)_{7} \mathrm{CO}_{2} \mathrm{H} \frac{\mathrm{DMSO}}{100^{\circ} \mathrm{C}} \rightarrow \\
\left\{\begin{array}{c}
\mathrm{CH}_{3}\left(\mathrm{CH}_{2}\right)_{7}-\mathrm{C}-\mathrm{CH}\left(\mathrm{CH}_{2}\right)_{7} \mathrm{CO}_{2} \mathrm{H} \\
\mathrm{O} \text { OH } \\
\quad(\text { 収率 } 60 \sim 65 \%, \text { 二異性体) } \\
\mathrm{CH}_{3}\left(\mathrm{C}_{2}\right)_{7(8)}-\mathrm{C}-\left(\mathrm{CH}_{2}\right)_{8(7)}-\mathrm{CO}_{2} \mathrm{H} \\
\text { O } \quad(\text { 收率 } 15 \sim 20 \%) \\
\mathrm{CH}_{3}\left(\mathrm{CH}_{2}\right)_{7}-\mathrm{CH}-\mathrm{CH}-\left(\mathrm{CH}_{2}\right)_{7} \mathrm{CO}_{2} \mathrm{H} \\
\text { OH OH } \quad \text { (収率 } 15 \sim 20 \%)
\end{array}\right.
\end{gathered}
$$

エポキシドを三フッ化ホウ素触媒存在下，ジメチルス ルホキシド中で反応させると $\alpha$-オキシケトンが得られ るが ${ }^{34)}$ ，八ロゲン化アルキルを共存させることによりカ ルボニル化合物が高收率で得られる。たとえば，cis-4， 5-エポキシオクタンからは次図に示す経路を通ってオク $\mathrm{PrI}+\mathrm{Me}_{2} \mathrm{SO} \rightleftharpoons \mathrm{Me}_{2} \stackrel{+}{\mathrm{SO}} \mathrm{OPr}+\mathrm{I}^{-}$

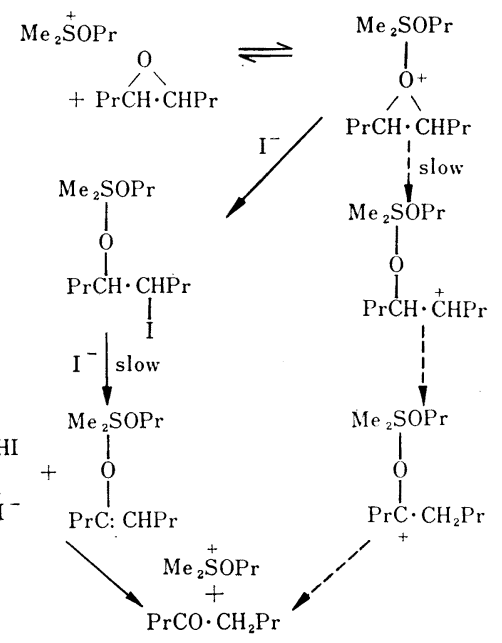

ただしPrは $\mathrm{CH}_{3} \mathrm{CH}_{2} \mathrm{CH}_{2}^{-}$ 
タン-4-オンが収率 100\% で得られる35)。

そのほかに, $\mathrm{NaI}^{36)}, \mathrm{LiClO}_{4}{ }^{37)}, \mathrm{H}_{2} \mathrm{O}_{2}{ }^{38)}$ などを作用さ せてもカルボニル化合物が得られる。

\section{$4 \cdot 6$ 第ニアルコールを経由する方法}

第二アルコールを脱水素あるいは酸化することにより ケントが得られる。

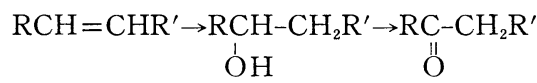

$4 \cdot 6 \cdot 1$ オレフィンから第二アルコールを得る方法

i ）硫酸化によるヒドロキシル化は, 重要な低級アル コール製造法であるが, 高級オレフィンでは副反応を伴 う。たとえば, オレイン酸を硫酸化後, 加水分解すると 9- あるいは 10-モノヒドロキシステアリン酸の混合物 が得られる ${ }^{39) 。 ~}$

$$
\begin{aligned}
& \mathrm{CH}_{3}\left(\mathrm{CH}_{2}\right)_{7} \mathrm{CH}=\mathrm{CH}\left(\mathrm{CH}_{2}\right)_{7} \mathrm{CO}_{2} \mathrm{H} \stackrel{\mathrm{H}_{2} \mathrm{SO}_{4}}{\rightarrow} \\
& \mathrm{H}
\end{aligned}
$$

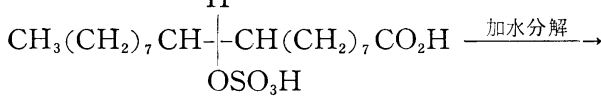

$$
\begin{aligned}
& \mathrm{CH}_{3}\left(\mathrm{CH}_{2}\right)_{7} \mathrm{CH}-\mathrm{H}-\mathrm{CH}\left(\mathrm{CH}_{2}\right)_{7} \mathrm{CO}_{2} \mathrm{H}
\end{aligned}
$$

ii ）酸性触媒たとえば過塩素酸，硫酸あるいは三フッ 化ホウ素-酢酸錯化合物または陽イオン交換樹脂の存在 下, ギ酸, 酢酸などの低級脂肪酸を付加させたのち, 加 水分解する ${ }^{40)}$ 。

$$
\begin{aligned}
& \mathrm{CH}_{3}\left(\mathrm{CH}_{2}\right)_{7} \mathrm{CH}=\mathrm{CH}\left(\mathrm{CH}_{2}\right)_{7} \mathrm{CO}_{2} \mathrm{H} \underset{\text { RCOOH }}{\text { 触媒 }} \rightarrow \\
& \mathrm{H}
\end{aligned}
$$

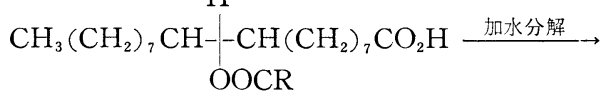

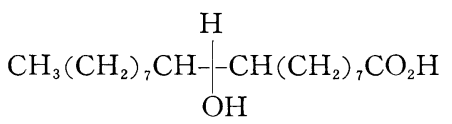

iii）オレフィンをジボランで処理してトリアルキルボ ランとし，これを過酸化水素で酸化すると容易に水和反 応が行なわれる。二重結合が分子の端にあるオレフィン は第一アルコール, 分子の内部にあるオレフィンはそれ ぞれの位置に水和したアルコールが生成するが，二重結 合が内部にある場合でもトリアルキルボランを $160^{\circ} \mathrm{C}$ に加熱したのちに酸化すると第一アルコールが得られ る41。しかし，オレイン酸メチルの場合には加熱しても 移動は起こらない(42)。

$$
\begin{aligned}
& \mathrm{RCH}=\mathrm{CHCH}_{3} \frac{\mathrm{B}_{2} \mathrm{H}_{6}}{\text { in ether }} \rightarrow \underset{\text { 采 }}{\mathrm{R}} \mathrm{H}-\mathrm{CH}_{2} \mathrm{CH}_{3}
\end{aligned}
$$

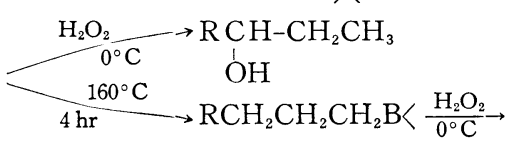

$$
\begin{aligned}
& \mathrm{RCH}_{2} \mathrm{CH}_{2} \mathrm{CH}_{2} \mathrm{OH}
\end{aligned}
$$

iv） $\alpha$-オレフィンからの 1,2-エポキシドをラネーニ ッケル触媒で接触還元すると第一アルコールを多く生ず るが ${ }^{43)}$ ，パラジウム触媒を用いるか，水酸化ナトリウム またはハロゲン化アルキルなどを添加すると第二アルコ ールの生成割合が増加する ${ }^{44)}$ 。

$$
\underset{\mathrm{O} /}{\mathrm{RCH}-\mathrm{CH}_{2}} \frac{\mathrm{H}_{2}}{\text { 触媒 }} \rightarrow \underset{1}{\mathrm{OH}} \rightarrow \mathrm{RCH}_{2} \mathrm{CH}_{2} \mathrm{OH}+\underset{\mathrm{HCH}}{\mathrm{R}} \mathrm{HCH}_{3}
$$

cis-および trans-9,10-エポキシステアリン酸あるい はそれらのメチルエステルを $10 \% \mathrm{Pd}-\mathrm{C}$ 触媒を用い， 酢酸中，室温で水素添加すると，10-ヒドロキシステア リン酸あるいはメチルエステルが得られる ${ }^{45)}$ 。

$$
\begin{aligned}
& \mathrm{CH}_{3}\left(\mathrm{CH}_{2}\right)_{7} \mathrm{CH}-\mathrm{CH}\left(\mathrm{CH}_{2}\right)_{7} \mathrm{CO}_{2} \mathrm{R} \frac{\mathrm{H}_{2}}{\mathrm{Pd}-\mathrm{C} \text { 种媒 }} \rightarrow \\
& \mathrm{CH}_{3}\left(\mathrm{CH}_{2}\right)_{7} \mathrm{CH}-\mathrm{CH}_{2}\left(\mathrm{CH}_{2}\right)_{7} \mathrm{CO}_{2} \mathrm{R} \\
& \mathrm{O} \mathrm{H}
\end{aligned}
$$

オレフィンからのエポキシドをエーテル中, $\mathrm{LiAlH}_{4}$ で還元してもアルコールが得られるが46)，オレイン酸か らのエポキシドを $\mathrm{LiAlH}_{4}$ で還元するとカルボキシル 基も還元されてオクタデカン-1,10-ジオールを与え $3^{47)}$ 。

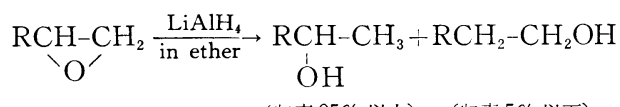

$$
\begin{aligned}
& \text { （収率 } 95 \% \text { 以上）（収率 } 5 \% \text { 以下） } \\
& \mathrm{CH}_{3}\left(\mathrm{CH}_{2}\right)_{7} \mathrm{CH}-\mathrm{CH}\left(\mathrm{CH}_{2}\right)_{7} \mathrm{CO}_{2} \mathrm{H} \frac{\mathrm{LiAlH}_{4} \text {, in ether }}{\text { 收率 } 80 \%} \rightarrow \\
& \mathrm{CH}_{3}\left(\mathrm{CH}_{2}\right)_{7} \mathrm{CH}-\mathrm{CH}_{2}\left(\mathrm{CH}_{2}\right)_{7} \mathrm{CH}_{2} \mathrm{OH} \\
& \mathrm{OH}
\end{aligned}
$$

また，エポキシドをナトリウムアマルガムで還元して も第二アルコールが得られる ${ }^{48)}$ 。

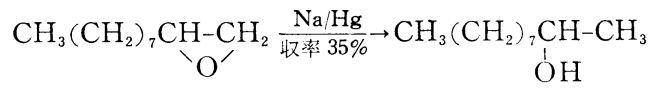

v) オレフィンを水-テトラヒドロフラン (1:1) 混 合溶媒中で酢酸水銀を反応させて得られた水銀中間体を 取り出さないで, そのままアルカリ性で水素化ホウ素ナ トリウムで還元（脱水銀化）すると二重結合への Markovnikov 則による水和が高収率で起こる ${ }^{49)}$

$$
\begin{aligned}
& \mathrm{RCH}=\mathrm{CH}_{2}+\mathrm{Hg}(\mathrm{OAc})_{2}
\end{aligned}
$$

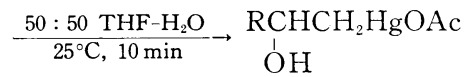

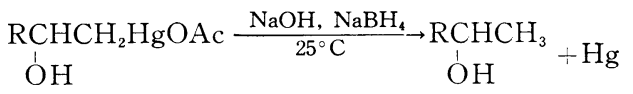

たとえば，1-ドデセンから 2-ドデカノール（収率 91 \%)，1-オクタデセンから 2-オクタデカノール（収率 93\%) が得られる。

そのほかに, 不飽和脂肪酸の自動酸化生成物を還元す る方法 ${ }^{50)}$ などもある。 
$4 \cdot 6 \cdot 2$ 第二アルコールからケトンを得る方法

i ） 12-ヒドロキシステアリン酸メチルにラネーニッ ケルあるいは銅クロマイト触媒を加え, 加熱すると脱水 素反忘が起こり, 高純度の 12-ケトステアリン酸メチル が高収率で得られる ${ }^{51)}$ 。

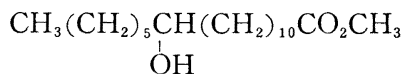
$\mathrm{OH}$

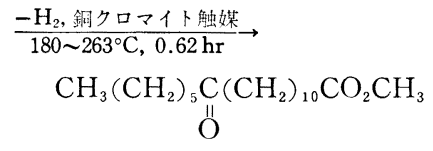
収率 $99 \%$ (純度 $97 \%$ )

ii）ヒドロキシ酸を無水クロム酸一酢酸 ${ }^{52)}$, 重クロム酸ナトリウム ${ }^{53)}$ ，クロム第三ブチル ${ }^{54)}$ などによ る酸化あるいは Oppenauer 酸化 ${ }^{55}$ によりケト酸が得ら れる。

$$
\begin{gathered}
\mathrm{CH}_{3}\left(\mathrm{CH}_{2}\right)_{5} \mathrm{CHCH}_{2} \mathrm{CH}=\mathrm{CH}\left(\mathrm{CH}_{2}\right)_{7} \mathrm{CO}_{2} \mathrm{H} \\
\stackrel{\mathrm{CrO}_{3}-\mathrm{CH}_{3} \mathrm{COOH}}{30 \sim 40^{\circ} \mathrm{C}} \rightarrow \\
\mathrm{CH}_{3}\left(\mathrm{CH}_{2}\right)_{5} \mathrm{CCH}_{2} \mathrm{CH}=\mathrm{CH}\left(\mathrm{CH}_{2}\right)_{7} \mathrm{CO}_{2} \mathrm{H}
\end{gathered}
$$

6,7-エポキシオクタデカン酸の $\mathrm{LiAlH}_{4}$ 還元生成物 であるオクタデカン-1,7-ジオ一ルを無水クロム酸-酢酸 で酸化すると 7-ケトオクタデカン酸が得られる ${ }^{56)}$ 。

$$
\begin{aligned}
& \mathrm{CH}_{3}\left(\mathrm{CH}_{2}\right)_{10} \mathrm{CH}-\mathrm{CH}\left(\mathrm{CH}_{2}\right)_{4} \mathrm{CO}_{2} \mathrm{H} \\
& \stackrel{\mathrm{LiAlH}_{4}}{\text { in ether }} \rightarrow \mathrm{CH}_{3}\left(\mathrm{CH}_{2}\right)_{10} \mathrm{CH}-\mathrm{CH}_{2}\left(\mathrm{CH}_{2}\right)_{4} \mathrm{CH}_{2} \mathrm{OH} \\
& \stackrel{\mathrm{O}}{\mathrm{CrO}_{3}-\mathrm{CH}_{3} \mathrm{COOH}} \rightarrow \mathrm{CH}_{3}\left(\mathrm{CH}_{2}\right)_{10} \mathrm{C}-\mathrm{CH}_{2}\left(\mathrm{CH}_{2}\right)_{4} \mathrm{CO}_{2} \mathrm{H} \\
& \mathrm{O}
\end{aligned}
$$

第二アルコールからケトンへの酸化剂としては，その 泳かに活性二酸化マンガン ${ }^{57)}$, ジメチルスルホキシド58), 鉄酸カリウ ( $^{59)}$, 四塩化炭素 ${ }^{60)}$, 塩化パラジウム ${ }^{61)}$ など があり， $\mathrm{Pt}-\mathrm{Al}_{2} \mathrm{O}_{3}$ あるいは $\mathrm{Rh}-\mathrm{Al}_{2} \mathrm{O}_{3}$ 触媒による接触 酸化 ${ }^{62}$ あるいは超音波により脱水素する方法 ${ }^{63)}$ などもあ る。

\section{$4 \cdot 7 \quad \boldsymbol{a}$-ジケトンを経由する方法}

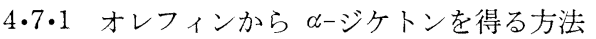

i ) 不飽和化合物を二酸化セレンで酸化するとジカル ボニル化合物が得られる。エチレンなど炭素数の少ない オレフィンについて認められており，一般には隣接基に 活性水素がないときに起こることが多い。たとえばスチ ルベンからベンジルが得られる ${ }^{64)}$ 。

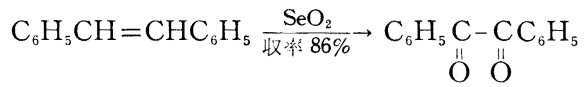

ii) J.E. Coleman $5^{65}$ はオレイン酸を非イオン乳化 剤で水中に乳化し， pH 6〜7 で過マンガン酸カリウム
で酸化することにより 9,10 -ジケトステアリン酸を 25 \%の収率で得ている。また, K.B. Sharpless ら ${ }^{66)}$ は大 環状オレフィンおよび鎖状オレフィンを無水酢酸中, 過 マンガン酸カリウムで注意して酸化することにより収率 よく よージケトンを得た。

$$
\mathrm{H}_{3}\left(\mathrm{CH}_{2}\right)_{7} \mathrm{CH}=\mathrm{CH}\left(\mathrm{CH}_{2}\right)_{7} \mathrm{COOH} \underset{\text { 收摔 } 42 \%}{\longrightarrow} \mathrm{CH}_{3}\left(\mathrm{CH}_{2}\right)_{7} \mathrm{C}-\mathrm{C}\left(\mathrm{CH}_{2}\right)_{7} \mathrm{COOH}
$$

iii）オレイン酸を過マンガン酸カリウム ${ }^{67)}$, 四酸化才 スミウ ${ }^{68)}$, 過硫酸 ${ }^{69)}$, 安息香酸 $ヨ$ ウ化銀 ${ }^{70)}$, 四酢酸 鉛 $^{71)}$ ，過ギ酸 ${ }^{72}$ あるいは過酢酸 ${ }^{73)}$ などの有機過酸，過酸 化水素とタングステン酸 ${ }^{74)}$, 過酸化水素とトリフルオル 酢酸 ${ }^{75)}$ などによる酸化，あるいは酢酸溶液中でのヨウ素 と酢酸銀処理 ${ }^{76)}$ ，電解酸化 ${ }^{77)}$ な゙により 9,10 -ジヒドロ キシステアリン酸が得られる。このジヒドロキシ酸の酢 酸溶液に無水クロム酸の濃硫酸を含屯酢酸溶液を加えて 酸化すると 9,10 -ジケトステアリン酸が収率 $25 \%$ で得 られる ${ }^{78)}$ 。

$$
\begin{aligned}
& \mathrm{CH}_{3}\left(\mathrm{CH}_{2}\right)_{7} \mathrm{CH}=\mathrm{CH}\left(\mathrm{CH}_{2}\right)_{7} \mathrm{CO}_{2} \mathrm{H} \\
& \rightarrow \mathrm{CH}_{3}\left(\mathrm{CH}_{2}\right)_{7} \mathrm{CH}-\mathrm{CH}\left(\mathrm{CH}_{2}\right)_{7} \mathrm{CO}_{2} \mathrm{H}
\end{aligned}
$$

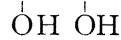

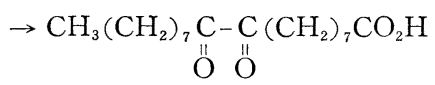

9,10,16-トリヒドロキシへキサデカン酸と N-ブロム スクシンイミドを酶酸エチルと水の混液中で加熱還流す ることにより 9,10-ジケト-16-ヒドロキシヘキサデカン 酸が収率 $30 \%$ で得られる

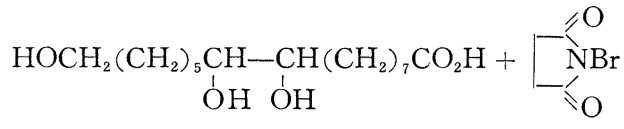

$15 \mathrm{~min}$, 還流

in $\mathrm{CH}_{3} \mathrm{CO}_{2} \mathrm{C}_{2} \mathrm{H}_{5}-\mathrm{H}_{2} \mathrm{O}$

$$
\mathrm{HOCH}_{2}\left(\mathrm{CH}_{2}\right)_{5} \underset{\mathrm{O}}{\mathrm{C}}-\mathrm{O}\left(\mathrm{O}\left(\mathrm{CH}_{2}\right)_{7} \mathrm{CO}_{2} \mathrm{H}\right.
$$

また，ジオールを銅クロマイト触媒を用いる接触酸化

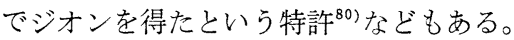

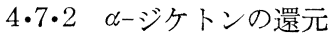

๙ージケトンをヨウ化水素酸で還元することによりモ ノケトンが得られる。たとえばオレイン酸, ペトロセリ ン酸およびエルシン酸の ๔-ジケトン誘導体を，47\% ヨ ウ化水素酸と水酢酸中で, $3 \mathrm{hr}$ 還流すると二種のモノ ケト酸の異性体混合物が結晶として単離される ${ }^{81)}$ 。また 環状 $ロ$-ジケトンあるいは $\alpha$-ケトールを同様に還元して もモノケトンが得られる ${ }^{82)}$ 。 


$$
\begin{aligned}
& \mathrm{RCH}=\mathrm{CHR}^{\prime}
\end{aligned}
$$

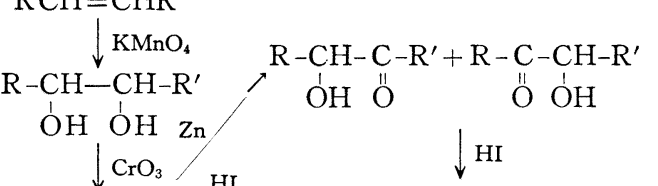

$$
\begin{aligned}
& \mathrm{R}-\mathrm{C}-\mathrm{C}-\mathrm{R}^{\prime} \longrightarrow \mathrm{HI} \longrightarrow \mathrm{R}-\mathrm{CH}_{2}-\mathrm{C}-\mathrm{R}^{\prime}+\mathrm{R}-\mathrm{C}-\mathrm{CH}_{2}-\mathrm{R}^{\prime} \\
& \text { O }{ }^{\| \prime} \quad \stackrel{\mathrm{O}}{\mathrm{O}} \\
& \mathrm{CH}_{3}\left(\mathrm{CH}_{2}\right)_{7^{-}},-\left(\mathrm{CH}_{2}\right)_{7} \mathrm{COOH} ; \mathrm{CH}_{3}\left(\mathrm{CH}_{2}\right)_{10^{-}} \text {, } \\
& -\left(\mathrm{CH}_{2}\right)_{4} \mathrm{COOH} ; \mathrm{CH}_{3}\left(\mathrm{CH}_{2}\right)_{7^{-}},-\left(\mathrm{CH}_{2}\right)_{11} \mathrm{COOH} \\
& (\overbrace{\left.\mathrm{CH}_{2}\right)_{8}}^{\mathrm{C}} \int_{\mathrm{C}=\mathrm{O}}^{\mathrm{C}}=\mathrm{H}
\end{aligned}
$$

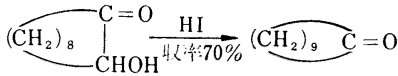

\section{5 おわりに}

著者の不勉強のため, 見落とした文献, 誤解がかなり 多いと思うが，読者諸氏の何らかの拈役にたてば幸いで ある。

\section{（昭和 47 年 9 月 12 日受理）}

\section{文献}

1) 橋本, 化学々工業, 20, 1077 (1967); 辻, 有合化, 25, 984 (1967); 斎藤, 油化学, 17, 287 (1958); 市川ら, 有 合化, 29, 400 (1971) なと

2) J. Smidt et al., Angew. Chem.: 71, 176 (1959)

3) W.H. Clement et al., J. Org. C'hem., 29, 241 (1964)

4) W.G. Lloyd et al., J. Org. Chem., 34, 3949 (1969)

5) B.C. Fieiding et al., J. Chem. Soc. (A), 1966, 1627

6) Y. Saito et al., J. Organometal. Chem., 10, 524 (1967)

7) R.R. Grintead, J. Org. Chem., 26, 238 (1961); P.M. Henry, J. Amer. Chem. Soc., 87, 990, 4423 (1965); 88, 1597 (1966); H.J. Kabble, Ann., 656, 204 (1962); J.B. Lee et al., Tetrahedron, 20, 1017 (1964); K. Ichikawa et al., ibid., 407 (1966); K.C. Pande et al., Tetrahedrom Letters, 3393 (1964); C.B. Anderson et al., J. Org. Chem., 28, 605 (1963); R.J. Ouellette et al., ibid., 34, 4104 (1969); 植村ら, 日化, 87, 986 (1966)

8) A. Mckillop et al., Tetrahedron Letters, 1970, 5275

9) F.S. Bridson-Jones et al., J. Chem. Soc., 1951, 2999, 3009

10) W.J. Hickinbotton et al., J. Chem. Soc., 1954, 4400

11) W.J. Hickinbotton et al., J. Chem. Soc., 1955, 1360

12）御園生ら, 油脂, 22, No. 5., 125 (1969)

13) V. Boekelheide et al., J. Amer. Chem. Soc., 72, 1245 (1950); L.F. Fieser, ibid., 75, 4377, 7386 (1953)

14) S.J. Cristol et al., J. Amer. Chem. Soc., 72, 4353 (1950); R.A. Stairs et al., Can. J. Chem., 41, 1059 (1963); C.N. Rentea et al., Tetrahedron, 22, 3501 (1966)

15) F. Freeman et al., J. Org. Chem., 33, 3970 (1968); J. Amer. Chem. Soc., 92, 4621 (1970)

16) R.N. McDonald et al., J. Amer. Chem. Soc., 85,
4004 (1963)

17) H. Hart et al., J. Org. Chem., 32, 2669 (1967)

18) J.P. Vila et al., Anales real. soc. espaũ., fis. y quim., 48 B, 273 (1952); Chem. Abstr., 47, 3802 (1953) ; St. Goldschmidt et al., Rec. trav. Chim., 67, 489 (1948); Chem. Abstr., 43, 1355 (1949); H. Hock et al., Chem. Ber., 83, 227 (1950); J.E. Horan et al "Organic Syntheses" Vol. 41, p. 53 (1961)

19) S. Suzuki et al., Ind. Eng. Chem. Prod. Res. Develop., 10, 179 (1971)

20) H.C. Brown et al., J. Amer. Chem. Soc., 83, 2951 (1961)

21) L.G. Wideman, J. Org. Chem., 33, 4541 (1968)

22) M.Ohno et al., Bull. Chem. Soc. Japan, 39, 1119 (1966)

23) E.J. Corey et al., J. Amer. Chem. Soc., 92, 5276 (1970)

24) H.R. Nace et al., J. Org. Chem., 24, 1792 (1959); A.P. Johnson et al., J. Chem. Soc., 1964, 520

25) D. Rankoff et al., Fette-Seifen Anstrichmittel, 70, 334 (1968)

26) D. Rankoff, J. Amer. Oil Chemists' Soc., 45, 744 (1968)

27) H. Newby, Brit. 879,803 (1961); Chem. Abstr., 57, 665 (1962)

28) L.J. Haynes et al., J. Chem. Soc., 1947, 1583

29) J.L. Eisenmann, J. Org. Chem., 27, 2706 (1962)

30) H.A. Walens et al., J. Amer. Oil Chemists'Soc., 42, 126 (1965)

31) H.B.S. Conacher et al., Chem. Phys. Lipids, 3, 203 (1969); Chem. Commun., 1967, 984; L. Canonica et al., Tetrahedron, 25, 1 (1969)

32) G. Kolaczinski et al., Fette $\cdot$ Seifen Anstrichmittel, 73, 553 (1971)

33) D. Swern, J. Amer. Oil Chemists' Soc., 47, 424 (1970)

34) T. Cohen et al., J. Org. Chem., 26, 1681 (1961)

35) D. Bethell et al., Chem. Commun., 1968, 227

36) G.W. Kenner et al., Acta Chem. Scand., 18, 1551 (1954)

37) B. Rickborn et al., J. Amer. Chem. Soc., 90, 4194 (1968)

38) А.П. Merewebuq, $Y C_{\pi} . X_{N M} ., 39(3), 444$ (1970)

39) E.T. Roe et al., J. Amer. Oil Chemists' Soc., 24, 45 (1947); G.V. Rao et al., ibid., 48, 286 (1970)

40) H.B. Knight et al., J. Amer. Chem. Soc., 75, 6212 (1953); J. Rockett, ibid., 78, 3191 (1956); H.B. Knight et al., J. Amer. Oil Chemists' Soc., 31, 1 (1954); W.O. Munns et al., ibid., 40, 22 (1963); L. T. Black et al., ibid., 44, 310 (1967)

41) Chem. Eng. News, 37, Jan. 19, 36 (1959); H.C. Brown et al., J. Amer. Chem. Soc., 88, 1443 (1966)

42) S.P. Fore et al., J. Org. Chem., 24, 920 (1959)

43) Henkel \& Cie. G.m.b.H., Ger. 1,139,477 (1962); Chem. Abstr., 58, 10079 (1963); R.T. O'Connor et al., J. Org. Chem., 18, 686, 693 (1953)

44) 三井ら，日化，86，225 (1965)

45) I.G.V. Pigulevskii et al., J. Gen. Chem. (USSR), 9, 829 (1939); Chem. Abstr., 34, 378 (1940); Z. Ya, Rubashko, J. Gen. Chem. (USSR), 34, 585 (1964); C.H. Mack et al., J. Org. Chem., 18, 686 (1953); R. Subbarao et al., Tetrahedron Letters, 1966, 379; 
G.V. Rao et al., J. Amer. Oil Chemists' Soc., 45, 408 (1968)

46) M.S. Newman, J. Amer. Chem. Soc., 71, 3362 (1949); C.R. Glowaoki et al., J. Amer. Oil Chemists' Soc., 47, 225 (1970)

47) G.V. Pigubevskii et al., J. Gen. Chem. (USSR), 31, 601, 605 (1961); Chem. Abstr., 55, 22120 (1961)

48) M.S. Newman, J. Amer. Chem. Soc., 71, 3362 (1949)

49) H.C. Brown et al., J. Amer. Chem. Soc., 89, 1522 (1967); J. Org. Chem., 35, 184 (1970)

50）足立“第 11 回関西夏季ゼミナール”テキスト (1970)

51) B. Freedman et al., J. Amer. Oil Chemists' Soc., 42, 340 (1965) ; 43, 125, 342 (1966) ; 47, 311 (1970)

52) J. Ross et al., J. Amer. Chem. Soc., 71, 282(1949); J. Rockett, ibid., 78, 3191 (1956); G.W. Ellis, J. Chem. Soc., 1950, 9; O. Grummitt et al., J. Amer. Oil Chemists' Soc., 26, 690 (1949)

53) J. Nichols, U.S. 2,623,888 (1952); Chem. Abstr., 47, 9999 (1953)

54) 丸田ら, 工化, 60, 31 (1957)

55）三原ら, 日化, 79, 282 (1958)

56) G.V. Pigulevskii et al., Zhur. Obshchei Khim., 31, 652, 656 (1961); Chem. Abstr., 55, 22120 (1961)

57) I.M. Goldman, J. Org. Chem., 34, 1979 (1969)

58) W.H. Clement et al., Chem. Ind. (London), 1969 (23), 755

59) R.J. Audette et al., Tetrahedon Letters, 1971, 279

60) W.J. Jackson, Ind. Eng. Chem. Prod. Res. Develop., 3, 100 (1964)

61) A.V. Nikiforova et al., Zh. Obshch. Khim., 33, 3239 (1963); Chem. Abstr., 60, 3995 (1964)

62) B.H. Davis et al., J. Catal., 13, 100 (1969); Chem. Abstr., 70, 77223 c (1969)

63) M. Anbar et al., J. Phys. Chem., 68, 1462 (1964); Chem. Abstr., 61, 2935 (1964)

64) S. Astin et al., J. Chem. Soc., 1935, 901
65) J.E. Coleman et al., J. Amer. Oil Chemists' Soc., 35, 675 (1958)

66) K.B. Sharpless et al., J. Amer. Chem. Soc., 93, 3303 (1971)

67) A. Lapworth et al., J. Chem. Soc. (London), 127, 1628 (1925)

68) A. Bader, J. Amer. Chem. Soc., 70, 3938 (1948)

69) I. Afanasievski, J. Russ. Phys. Chem. Soc., 47, 2124 (1915); Chem. Abstr., 10, 3060 (1916)

70) H. Wittcoff et al., J. Amer. Chem. Soc., 69, 3138 (1947)

71）松原ら, 日化, 80, 1195 (1957); 工化, 63, 502, 505, (1960)

72) D. Swern et al., J. Amer. Chem. Soc., 67, 1786 (1945)

73) G. King, J. Chem. Soc., 1943, 37

74) T.M. Luong et al., J. Amer. Oil Chemists' Soc., 44, 316 (1967); G.O. Hustad et al., ibid., 47, 333 (1970)

75) W.D. Emmons et al., J. Amer. Chem. Soc., 76, 3472 (1954)

76) F.D. Gunstone et al., J. Chem. Soc., 1957, 487

77) 丸田, 日化, 72, 233 (1951)

78) B.H. Nicolet et al., J. Amer. Chem. Soc., 44, 1136 (1922); S.M. Osman et al., Fette $\cdot$ Seifen Anstrichmittel, 72, 454 (1970)

79) C.A. Grob et al., Helv. Chim. Acta, 36, 1763 (1953); M.F. Ansell et al., J. Chem. Soc. (C), 1971, 1846

80) O.J. Weinkauff, U.S. 2,455,631 (1948); Chem. Abstr., 43, 1797 (1949)

81) S.M. Osman et al., Fette-Seifen Anstrichmittel, 72, 454 (1970)

82) W. Reusch et al., J. Amer. Chem. Soc., 86, 3068 (1964) 